Bulletin d'Histoire Contemporaine de l'Espagne

$54 \mid 2020$

Les espaces du politique dans l'Espagne du Trienio liberal (1820-1823)

\title{
La milicia nacional o la ciudadanía armada. El contrapoder revolucionario frente al liberalismo institucional
}

La milice nationale ou la citoyenneté armée. Le contre-pouvoir révolutionnaire face au libéralisme institutionnel

National militia or armed citizenship. The revolutionary counter-power against institutional liberalism

Jordi Roca Vernet

\section{(2) OpenEdition}

\section{Journals}

Edición electrónica

URL: http://journals.openedition.org/bhce/2598

DOI: 10.4000/bhce. 2598

ISSN: 1968-3723

\section{Editor}

Presses Universitaires de Provence

\section{Edición impresa}

Fecha de publicación: 1 enero 2020

ISSN: 0987-4135

\section{Referencia electrónica}

Jordi Roca Vernet, « La milicia nacional o la ciudadanía armada. El contrapoder revolucionario frente al liberalismo institucional », Bulletin d'Histoire Contemporaine de l'Espagne [En línea], 54 | 2020

Publicado el 01 julio 2020, consultado el 30 diciembre 2020. URL : http://journals.openedition.org/ bhce/2598; DOI : https://doi.org/10.4000/bhce.2598

Este documento fue generado automáticamente el 30 diciembre 2020.

Bulletin d'histoire contemporaine de l'Espagne 


\section{La milicia nacional o la ciudadanía armada. El contrapoder revolucionario frente al liberalismo institucional}

La milice nationale ou la citoyenneté armée. Le contre-pouvoir révolutionnaire face au libéralisme institutionnel National militia or armed citizenship. The revolutionary counter-power against institutional liberalism

Jordi Roca Vernet

\section{Introducción}

1 Desde hace décadas la historiografía sobre la Milicia Nacional (MN) tiene dos líneas principales de estudio, una iniciada por Roberto Blanco Valdés ${ }^{1}$ sobre la evolución y transformación de las fuerzas armadas durante el primer liberalismo, y la otra comenzada por Juan Sisinio Pérez Garzón ${ }^{2}$ con estudios de caso sobre la Milicia en las principales ciudades y regiones españolas. En estos últimos años se hace recurrentemente un análisis sociológico, un estudio de reglamentos de los batallones, se describen los enfrentamientos militares entre milicianos y realistas, y en numerosas ocasiones se interpreta qué papel jugaron en la confrontación entre instituciones (ayuntamiento y diputación); excepcionalmente se interesan por analizar cuál fue su participación en los motines de desobediencia cívica o en las jornadas revolucionarias.

2 Las principales aportaciones historiográficas sobre la MN del Trienio Liberal (1820-1823) se han realizado a través de estudios locales y regionales, ofreciendo multitud de datos e interpretaciones que resultan fundamentales para esta investigación. A continuación, recogemos algunos de los principales y más recientes trabajos. Conviene distinguir aquellos estudios específicos sobre la MN de las 
investigaciones dedicadas al periodo del Trienio en un territorio en concreto. Los estudios específicos sobre la MN son los de Claudio Calles ${ }^{3}$ dedicado a Salamanca, José María García León a Cádiz ${ }^{4}$, José Fermín Garralda Arizcun ${ }^{5}$ a Pamplona, Óscar González para León ${ }^{6}$, Francisco Dueñas ${ }^{7}$ a Barcelona, Rosa Ana Gutiérrez Lloret y Rafael Zurita ${ }^{8}$ a Alicante, Antoni Sánchez Carcelén ${ }^{9}$ y Quintí Casals ${ }^{10}$ a Lleida, Ramon Vallverdú a Reus ${ }^{11}$, Miguel Naranjo a Badajoz ${ }^{12}$, mientras los demás se ocupan monográficamente del Trienio Liberal, como ocurre con Matilde Codesal ${ }^{13}$ para el caso de Zamora, Antonio Guillén Gómez ${ }^{14}$ para Almería, María Teresa Garabain Aranguren ${ }^{15}$ para Rentería, Lara Martín-Portugués ${ }^{16}$ para Jaén, Luis Sorando Muzás ${ }^{17}$ para Zaragoza. Para territorios más grandes destacamos los estudios de Pedro Rújula ${ }^{18}$ para Aragón, Ramon Arnabat ${ }^{19}$ para Cataluña, Félix Llanos Aramburu ${ }^{20}$ para Guipúzcoa, Vicente Fernández Benítez ${ }^{21}$ para Santander, Xosé Ramón Veiga ${ }^{22}$ y Antonio Mejide Pardo ${ }^{23}$ para Galicia, Valentí Valenciano ${ }^{24}$ para Palma de Mallorca, Juan Díaz-Pintado ${ }^{25}$ para Castilla la Mancha, Manuel Chust ${ }^{26}$ para Valencia, etc.

3 En los últimos años se ha señalado que el origen de la MN estaba en las Milicias Provinciales que, con denominaciones y estructuras distintas, existieron en Europa y América desde el siglo XVI. En la monarquía hispánica se desarrollaron especialmente durante los reinados de los borbones, Felipe V y Carlos III. Juan Francisco Fuentes atribuye al protagonismo que tuvieron durante la Guerra de la Independencia contra las tropas napoleónicas la creación de las MN a través de la Constitución de $1812^{27}$. La MN era un cuerpo provincial, burgués y diferenciado del ejército regular que no podía actuar sin autorización de las Cortes más allá de su provincia de origen. Alberto Gil Novales $^{28}$, padre de los estudios modernos del Trienio Liberal, escribió que muy pronto muchos liberales tuvieron la sensación de que se quería retrasar y obstaculizar la formación del cuerpo.

4 La historiografía francesa lleva años escribiendo sobre la MN. De la mano de los nuevos enfoques sobre la Revolución Francesa se ha producido una renovación sobre los estudios de la Garde Nationale, con Roger Dupuy ${ }^{29}$ quien ha dado continuidad a los trabajos clásicos de Louis Girard ${ }^{30}$ y el más reciente de Georges Carrot $^{31}$. Dupuy retoma los estudios de Carrot en los que ponía el acento en la doble función de la Garde Nationale: por un lado, el mantenimiento del orden público, que la conectaba con las milicias burguesas del Antiguo Régimen, dedicadas a la protección de bienes y personas contra las violencias populares; y por el otro, la función democrática, que exaltaba la solidaridad unánime del Tercer Estado en favor de los ideales de justicia y libertad encarnados por la nación soberana. Su predecesor Louis Girard añadía una tercera función, la defensa de las nuevas instituciones no solo contra los aristócratas sino contra la coalición de "déspotas exteriores», que no era compartida por Carrot, quien consideraba que la movilización militar de los ciudadanos se distinguiría de las funciones políticas precedentes.

5 La investigación de Dupuy afirma que la Garde Nationale surge de la confrontación entre la exaltación democrática del pueblo en armas y la necesidad de mantener el orden público por parte de las nuevas autoridades, estimándola indispensable y esperan que lo garantice mediante el consenso cívico más que con el rigor de la ley. Dupuy ha estudiado cuáles fueron los factores que incentivaron la movilización popular y al mismo tiempo cuáles los limitaron: criterios censitarios de reclutamiento, creación de unidades de soldados, unidades de elite auto-equipadas (caballería, artillería, etc.) y la composición y estructura de los estados mayores. También apunta que en el devenir de 
los poderes políticos de la revolución significó un incremento de la preocupación por limitar el armamento popular que garantizaba el mantenimiento de los principios revolucionarios. También crecieron los miedos entre los moderados, lo que facilitó la injerencia creciente del ejército en detrimento de la Garde Nationale. Dupuy demuestra que la represión de la corriente democrática e insurreccional de la Garde Nationale incitó a sus miembros a refugiarse en la clandestinidad y a ramificarse en sociedades secretas que desarrollaron una cultura del complot, que se extendió a lo largo del siglo XIX, facilitando así el mantenimiento de la institución. La principal aportación de Dupuy es identificar la Garde Nationale con la voluntad de institucionalizar el derecho de insurrección y jugar un rol determinante en la lucha contra los privilegios nobiliarios en todas sus formas. Finalmente, en la medida que se imponga el triunfo del sufragio universal, que aparece en la Tercera República como el triunfo diferido de los principios de la revolución, el derecho de insurrección perderá legitimidad a pesar de la fascinación que ejerce la promesa de democracia directa, y la Garde Nationale será condenada.

6 Este artículo demostrará que la MN fue un espacio determinante para la politización de la ciudadanía, convirtiéndola en el lugar preeminente de difusión y reformulación de las ideas liberales entre los ciudadanos. Durante el Trienio Liberal, la Milicia Nacional Voluntaria (MNV) se erigió en un marcador de identidad política asociado al liberalismo exaltado, lo que no quiere decir que los moderados no participaran en ella; lo hicieron sin embargo en menor proporción, con menos entusiasmo y $\sin$ instrumentalizarla para movilizar a la ciudadanía con el fin de presionar a gobiernos e instituciones. La MN ejerció una cuádruple función: la primera, garantizaba la defensa del régimen liberal contra enemigos interiores y exteriores; la segunda, interpretaba el devenir y los límites de la revolución; la tercera, preservaba el orden público de cualquier tipo de alteración sociopolítica en un sentido u otro; y la última, incentivaba el aprendizaje de la participación de la ciudadanía en la política.

7 Desde un enfoque político, la MN puede analizarse a través de nuevas perspectivas que nos permitan reinterpretar el rol que desempeñó en los procesos de politización de las clases populares y medias durante el Trienio Liberal. A continuación, enumeraremos la propuesta de líneas de estudio para desarrollarlas posteriormente: en primer lugar, analizar la formación de batallones de la MN más allá de los reglamentos nacionales de la milicia, pues estos no siempre fueron un límite efectivo para impedir la presencia de aquellos que estaban excluidos de la condición de ciudadanos. La permeabilidad social de los batallones de la MN dependió del momento de su formación y de quienes tuvieron la iniciativa, lo que permite establecer si tenían una identidad revolucionaria o por el contrario perseguían contener o dividir el liberalismo insurreccional; la segunda, determinar los mecanismos establecidos por el poder institucional liberal para encauzar la deriva revolucionaria que suponía la organización de un liberalismo revolucionario sin demasiados mecanismos de control, convertido en una expresión permanente del pueblo en armas y de la pervivencia del derecho de rebelión; tercera, interpretar la proliferación de batallones y de unidades que se enfrentaron a la amenaza realista a partir de la primavera de 1822 y observar cómo se conformaron cuerpos expedicionarios para combatir a los rebeldes realistas e invasores franceses.

8 La hipótesis de este artículo es que debería interpretarse la movilización social de la MN en función de la permeabilidad social de sus batallones, de la proliferación del número de batallones que agrupaban individuos excluidos o desarrollaban funciones no 
previstas, de su capacidad de incidir en la acción política de las instituciones liberales, rompiendo el equilibrio constitucional, y de la pervivencia de un discurso revolucionario que garantizaba el derecho de resistencia frente a la autoridad cuanto esta desobedeciera los principios sobre los que se fundaba la revolución liberal, apelando a la «salvación de la nación» o a la defensa de la «salud del pueblo» cuando la acción gubernamental suponía una amenaza. Por lo tanto, el número y la procedencia social de los milicianos no pueden ser las únicas variables que expliquen el comportamiento de la MN y menos aún las normativas nacionales de la MN pueden definir la composición de ésta.

\section{Formación de la MN y composición social}

El primer reglamento de la MN se aprobó en abril de 1814 y cuando se produjo el restablecimiento del régimen constitucional las Cortes decretaron el 26 de abril de 1820 un nuevo reglamento, basado en el anterior. El reglamento fijaba que los milicianos debían costearse su uniforme, lo que ha sido interpretado por la historiografía como una limitación de acceso a los sectores populares ${ }^{32}$. No obstante, antes de la aprobación del reglamento provisional, ciudades como Barcelona o Cádiz tomaron medidas previas para la formación de la MN, siguiendo el reglamento de 1814, con lo que cada miliciano usaría el uniforme que conservara de cuerpos precedentes, aunque le otorga a este cuerpo primogénito un sentido más simbólico que un cometido específico ${ }^{33}$. Arnabat sostiene que la MNV se creó rápidamente en las grandes ciudades catalanas de modo que en Barcelona, apenas un mes después de proclamarse la Constitución, la MNV ya disponía de 600 voluntarios, al cabo de cuatro meses la cifra alcanzaba los 1.500 y en noviembre de 1820 ya eran $2.000^{34}$.

En Barcelona, Cádiz y probablemente también La Coruña o Valencia, la formación de la MN fue mucho más rápida porque gracias a las redes de conspiradores que se alistaron rápida y masivamente, al ver la posibilidad de armarse con celeridad y ejercer un liderazgo en el proceso revolucionario. También observamos que en aquellas ciudades, al constituirse sin el decreto del reglamento aprobado, los batallones de la MNV fueron muy permeables, lo que hizo que se alistaran trabajadores, jornaleros e incluso extranjeros residentes. Por el contrario, en otras ciudades como Almería ${ }^{35}$, Salamanca ${ }^{36}$, León ${ }^{37}$, Zamora ${ }^{38}$, San Sebastián ${ }^{39}$, Palma ${ }^{40}$, Tarragona ${ }^{41}$ o Lleida ${ }^{42}$ la creación de los batallones de la MNV fue tardía a partir de mediados de 1820 e incluso algunas se crearon a principios de 1821. Detrás de la formación de los batallones a menudo estuvieron las redes de revolucionarios y las primeras autoridades liberales de las localidades, aunque en aquellos lugares en los que la fundación de la MNV fue más tardía, vemos cómo las sociedades patrióticas asumieron el impulso o directamente organizaron la formación de batallones, como es el caso en Tolosa ${ }^{43}$ (Guipúzcoa), Santander ${ }^{44}$, Palma ${ }^{45}$, Villanueva de la Serena ${ }^{46}$ (Badajoz). En ocasiones, como en Barcelona, la Sociedad Patriótica Barcinonense de los Buenos Amigos, al verse obligada a cerrar a raíz de la nueva regulación gubernamental sobre sociedades patrióticas decidió solicitar la fundación de un batallón, el quinto de la MNV, con la finalidad de que se integraran sus socios, alistándose en él más de 500 liberales. No obstante, en otras ocasiones fueron los batallones los que fundaron sociedades como ocurrió en Salamanca ${ }^{47}$ o en algunos pueblos de Almería. 
11 La dirección de la MN fue un elemento fundamental para su formación, pues los comandantes lideraban tanto la interpretación de los reglamentos como de la acción política de la MN para presionar a las instituciones. En Barcelona la formación de la Milicia estuvo liderada por el coronel retirado, José Costa, quien junto a otros exmilitares aprovecharon la oportunidad que les brindaba la formación de la MN para integrar todos los conspiradores que habían participado en los pronunciamientos de 1817 y 1820. Por lo tanto, la MN se convertía en un contrapoder armado al frente del cual estaban los grupos más beligerantes contra el régimen absolutista, que vigilarían el devenir de la revolución. La celeridad de la organización de la MN y la condición de la oficialidad de la MN fue determinante en la interpretación laxa del reglamento. Sin embargo, no ocurrió lo mismo en todas partes, pues en otras localidades el retraso en su formación -como sucedió en Salamanca ${ }^{48}$ - o la presencia de moderados en la dirección de la MN -como en Cádiz ${ }^{49}$, Zamora ${ }^{50}$ o Madrid ${ }^{51}$-, condicionaron la formación de la MN y su acción política como remanente del liberalismo revolucionario.

En agosto de 1820 las Cortes aprobaron un nuevo reglamento que excluía de la MN a distintos grupos socio-profesionales, como los funcionarios, médicos y catedráticos y a los jornaleros, lo que ha llevado a la historiografía a afirmar que la MN era un grupo con un predominio de las clases medias y del artesanado ${ }^{52}$. El sistema de provisión de empleos era electivo y la MN era dependiente de la autoridad civil superior. El reglamento preveía la obligación de alistarse a la MN y a partir de octubre de 1820 se llevó a cabo el alistamiento forzoso, pero como subraya R. Arnabat ${ }^{53}$ encontró un amplio rechazo en Cataluña, donde los que se alistaron se integraron en batallones a menudo denominados Milicia Nacional Reglamentaria o Legal (MNL). No obstante, Arnabat insiste en que estos milicianos prodigaron poco entusiasmo y fueron de menor utilidad al no servir armados muchos de ellos. La obligatoriedad de servir en la MN acrecentó el miedo a armar ciudadanos contrarios al liberalismo, en particular allí donde el liberalismo tenía un arraigo menor, como sucedió en Salamanca ${ }^{54}$ o Pamplona ${ }^{55}$, donde una parte significativa de los milicianos simpatizaban con las ideas realistas. Aquellos milicianos antiliberales se habían incorporado mayoritariamente en la MNV con el fin de aprovechar la ocasión para armarse y defender sus intereses. Por lo tanto, en aquellas ciudades las clases populares, básicamente jornaleros y artesanos, se habrían alistado a la milicia, prefigurando una identidad realista, lo que demostraría que la variable sociológica sobre la milicia debe interrelacionarse con la territorial, local o regional. En el reglamento de agosto cabía la posibilidad de que mediante una colaboración económica los ciudadanos quedaran exentos del servicio en la $\mathrm{MN}^{56}$. En el reglamento adicional de 4 de mayo de 1821 se favorecía la admisión de milicianos con el fin de promover el crecimiento de la MNL, pero se reforzaban las competencias municipales en la admisión, organización y financiación del cuerpo, lo que implicaba que la diputación y el jefe político perdían competencias y, como afirma Codesal, las autoridades centrales establecían un sistema de contrapesos para evitar la hegemonía de una institución sobre la $\mathrm{MN}^{57}$. También, como sugiere Calles, se facilitaba a los milicianos alistados a la MNL a pasar a la MNV con el fin de aseverar el compromiso con el liberalismo ${ }^{58}$, y probablemente con el objetivo de desnaturalizar social e ideológicamente las unidades precedentes.

Habitualmente los datos sobre el número de milicianos han despertado un inusitado interés. Para el caso de Barcelona, Dueñas ${ }^{59}$ afirma que se integraron 4.000 milicianos; no obstante, Arnabat rebaja la cifra a $3.000^{60}$. En Reus se alcanzó los 2.216 milicianos ${ }^{61}$ 
en 1823, mientras en Lleida llegó a los $171^{62}$. Arnabat supone que probablemente el número de milicianos en Cataluña llegó hasta los $12.000^{63}$. En Madrid, según los datos de Pérez Garzón, alcanzó en 1821 los 2.655 con 3 batallones, en Valencia José de Orga sugiere que había 2.07564; en Alicante había 1.735 repartidos en 4 batallones ${ }^{65}$; en Zaragoza había 2.201 en julio de $1822^{66}$, en Cádiz según García León unos 3.000 voluntarios; en Santander 1.000; en Zamora ${ }^{67} 622$, en Salamanca ${ }^{68} 500$, en León $622^{69}$, y en Palma $261^{70}$. Arnabat estima que para el conjunto de los territorios europeos de la monarquía habría unos 32.000 milicianos, lo que le lleva a concluir que uno de cada tres milicianos de la monarquía era catalán ${ }^{71}$.

Desde la perspectiva sociológica el debate político de los coetáneos liberales giró alrededor de cuál era el significado del concepto jornalero que se mencionaba en el reglamento ${ }^{72}$, por lo que numerosas localidades (Salamanca, Alicante ${ }^{73}$, etc.) solicitaron que se les aclarara su significado. La investigación de Arnabat demuestra que hubo una destacada presencia de jornaleros y payeses en localidades catalanas como Lleida, Calella, Vilanova i la Geltrú o Sant Sadurní d'Anoia ${ }^{74}$, pero en Alicante o Salamanca también hubo jornaleros entre las filas de la MN, lo que contradecía el reglamento aprobado en Cortes. Los liberales de los años veinte también debatieron sobre la presencia de los artesanos de la MNV, particularmente en las sociedades patrióticas de Madrid, que interpretaron la obligación de los milicianos de pagarse el uniforme como una forma de impedir el acceso de los artesanos a la milicia, por lo que algunos liberales plantearon la posibilidad de que los artesanos sirvieran sin uniforme o que se incentivase a los ciudadanos ricos a costear el uniforme de sus conciudadanos artesanos a través de suscripciones populares como las organizadas por la Sociedad Patriótica Lorencini ${ }^{75}$ y por la Sociedad Patriótica de San Sebastián de la Corte ${ }^{76}$, lo que demuestra las reticencias que encontró el liberalismo popular para incorporarse a la MNV de Madrid.

El caso madrileño no tuvo nada que ver con lo que ocurrió con la formación de la MNV en Barcelona o Cádiz donde los artesanos y menestrales coparon las filas de los primeros batallones, algo que también se produjo en Vic o Reus unos meses después. En Reus y $\mathrm{Vic}^{77}$ la mitad de los milicianos eran artesanos, menestrales y tejedores ${ }^{78}$, y en Lleida un tercio ${ }^{79}$. Una proporción menor había en Salamanca ${ }^{80}$. A finales de 1822 en Madrid la situación había cambiado por completo, según los datos de Pérez Garzón ${ }^{81}$ quien constata la presencia de 514 artesanos, distribuidos entre el segundo y tercer batallón, lo que suponía la mitad de los milicianos de los batallones y una cuarta parte del total de milicianos madrileños ${ }^{82}$. No sabemos exactamente cuándo se alistaron los artesanos a las filas de la MN y resulta probable que algunos de ellos lo hicieran después de que la MN evitara el golpe militar de las fuerzas reaccionarias, el 7 de julio de 1822, lo que instauró un culto cívico hacia la milicia madrileña. El estudio de Arnabat radiografía sociológicamente la MNV y MNL catalanas, siendo el único de estas características en el conjunto de los estudios sobre la $\mathrm{MN}$, considerando que la composición social de la MNL reflejaba mejor la estructura social de los propietarios y de clases acomodadas, y a su vez estaban menos identificados con el régimen liberal que los milicianos de la MNV ${ }^{83}$. Por otra parte, Fermín Muñoz Echabeguren ${ }^{84}$ demuestra que en ayuntamientos como el de San Sebastián se publicó una orden para que se contratara preferentemente a aquellos artesanos inscritos en la MNV en detrimento de los demás, lo que llevó a algunos a incorporarse a las filas de la milicia para conseguir trabajo, como apunta Carlos Rilova ${ }^{85}$, a partir de los motivos expuestos por el miliciano Juan José Azpe en el proceso de depuración abierto contra él por las autoridades 
absolutistas cuando regresaba a casa. Más allá de la dificultad de definir las categorías sociales, estos últimos datos relativizan la vinculación ideológica de algunos grupos sociales.

Para interpretar la proyección social de la MN resulta relevante analizar las suscripciones populares de la MN que revelan cuáles eran sus prioridades y en qué condiciones se encontraban sus miembros. En numerosas ciudades se organizaron suscripciones para financiar los uniformes de los milicianos (Santander ${ }^{86}$; Barcelona; Palma; Madrid; Salamanca) o en ocasiones se recaudaban fondos para que un grupo de mujeres, la mayoría vinculadas a través de familiares directos con el régimen liberal, se encargaran de coser capotes o uniformes, como ocurrió en Barcelona ${ }^{87}$ y Madrid ${ }^{88}$. También se organizaron suscripciones populares para dedicar los fondos a los artesanos sin ocupación ${ }^{89}$ para las familias pobres ${ }^{90} \mathrm{o}$ para ayudar a los jornaleros a pasar el verano ${ }^{91}$. De todos modos, lo más usual fue que se recaudaran fondos para las familias de los milicianos que estaban fuera de sus casas y no cobraban la retribución ${ }^{92} \mathrm{o}$ aquellas familias de milicianos heridos en combate. En algunas localidades como Barcelona, donde se refugiaron 1.500 milicianos $^{93}$ procedentes de otras localidades ocupadas por las tropas realistas, la situación de los milicianos se hizo insostenible, al coincidir que eran «muchísimos jornaleros que por razón de la actual crisis se han quedado sin trabajo $»^{94}$. Por ello, uno de los comandantes informó al ayuntamiento de cuál era la situación de «sus subordinados, reducidos a la extrema indigencia, pidiendo algunos, limosna y otros llenos de rubor postrados en una consternación deplorable» ${ }^{95}$. Aquello obligó a organizar una suscripción para auxiliar a los milicianos sin trabajo en la ciudad ${ }^{96}$ en la que colaboró el ayuntamiento que no podía hacer efectiva la resolución de la diputación de retribuir a los milicianos de fuera la ciudad como si fueran tropas regulares. Todos ello demuestra la preocupación de los milicianos por auxiliar a las familias y a los milicianos sin recursos o empobrecidos, ya fueran jornaleros o artesanos. La MN fue la organización más diversa socialmente, consiguiendo representar a las clases medias y populares.

17 A la luz de las evidencias de esta investigación, la permeabilidad de la MN de los sectores populares dependió no de sus reglamentos sino de cómo estos fueron interpretados por el jefe y comandantes de la milicia, designada por las autoridades locales y provinciales. Cuanto antes se constituyeron los batallones más permeables eran socialmente, y cuantos más se organizaron, mayor capacidad política tuvieron para hacer frente a los intentos posteriores de controlarlos. Conocer la adscripción social de los batallones resulta significativo porque permite conocer el grado de penetración de la movilización liberal entre la ciudadanía, pero sobre todo es relevante saber en qué condiciones estaban los milicianos y cómo interpretaron el lenguaje universalista del liberalismo en función de sus intereses políticos ${ }^{97}$. La MN sirvió como lugar de aprendizaje de la práctica reivindicativa y revolucionaria de aquellos grupos de artesanos y trabajadores, lo que se reflejó en la continuidad que tuvo la formación de batallones integrados exclusivamente por trabajadores de fábrica durante las décadas siguientes. En Barcelona se formó en 1836 el batallón denominado de la blusa, nombre que hacía referencia al atuendo típico de los trabajadores ${ }^{98}$, y alcanzó su mayor proyección política durante la revuelta de la «Jamancia» en 1843. En las dos décadas siguientes la experiencia política de los trabajadores manuales en la MN y en «los cuerpos de voluntarios» fue determinante para mostrar cómo se forjó su autonomía política y la formación de un discurso político propio o plebeyo, como ha explicado Albert García Balañáa9. Todo ello demuestra cómo después del Trienio se definió social e 
ideológicamente a los batallones de la MN según la significación política que había tenido la presencia de las clases populares en las revueltas o acciones revolucionarias del Trienio.

\section{Las formas de control sobre la Milicia Nacional Voluntaria} Fontana de Oro, para mostrar su desconfianza en el ejército por su sumisión al poder ejecutivo, por lo que interpretaba la MNV como un contrapeso democratizador desde el espacio local ante la tendencia a la concentración del poder político del ejecutivo. La MNV se convertía en un contrapoder que emanaba directamente del pueblo frente a los desmanes de un poder ejecutivo que podía usar el ejército contra las libertades de los ciudadanos ${ }^{100}$. Sin embargo, la historiografía ${ }^{101}$ ha preferido insistir más en la propuesta de un modelo de ejército mixto que recogiera unas «tropas de servicio continuo» y un numeroso contingente de «milicias nacionales» que en la desconfianza que generaba un ejército completamente sumido al poder del monarca y gobierno. En ciudades como Barcelona o Cádiz la MN actuó desde el primer momento como un auténtico contrapoder popular frente a los poderes liberales establecidos, en particular las Juntas provisionales, las Cortes y la diputación.

Muy pronto empezaron a escucharse voces en la capital catalana que pedían la formación de una cátedra de Constitución específicamente para milicianos ${ }^{102}$ con el fin de ilustrarlos en una lectura moderada de la norma constitucional como ya hacían instituciones educativas vinculadas a la Junta de Comercio, al Seminario Episcopal, las escuelas de la orden de los escolapios o un poco más tarde a la Universidad de $2^{\mathrm{a}}$ y $3^{\mathrm{a}}$ enseñanza ${ }^{103}$. Aquella situación obligó al ayuntamiento de Barcelona a buscar una alternativa, como fue la formación de la Academia Cívica para frenar la deriva revolucionaria del primer regimiento de la MNV que agrupaba a los dos primeros batallones. El proyecto remontaba a finales de abril, apenas unas semanas después de la formación de la MNV en Barcelona, aunque no empezó sus sesiones hasta noviembre de 1820 , cuando se respiraba una atmósfera moderada en la ciudad y se había acordado que no se formaría únicamente a milicianos. La Academia empezó sus clases en la sede de la cofradía de tejedores ante la negativa del ayuntamiento de habilitar el antiguo palacio de la Inquisición como había requerido su director Joaquín Catalá, corroborando la vinculación entre trabajadores y milicianos. La Academia reunía a más de medio millar de milicianos ${ }^{104}$, una tercera parte de los alistados en aquel momento, $y$ celebraba sus sesiones al final de la tarde para que estos pudieran compaginar las lecciones con su actividad laboral, vinculada a los talleres artesanales y las fábricas: los individuos de la milicia nacional y los pobres serán preferidos presentándose en un mismo tiempo con igualdad de motivos y mediante una certificación que lo justifique ${ }^{105}$. El objetivo de la Academia, como enunciaba Joaquín Catalá en un opúsculo, era interpretar adecuadamente la Constitución a la luz de los principios de la moderación y de la caridad evangélica, lo que denota que hasta entonces se interpretaba en un sentido más radical y menos abnegado a los principios de la iglesia católica. El discurso de Catalá demostraba que la Academia pretendía limitar la dimensión revolucionaria 
que tenía el discurso liberal entre las filas de los jóvenes artesanos que formaban la milicia de Barcelona, ya que se insistía en dirigirse exclusivamente a ellos.

Aquella igualdad tan mal entendida por los ignorantes, recibe en mi Plan sus reglas en el capítulo que trata de los pobres, en que asimismo he procurado brillara la caridad heroica hacia el indigente, socorriéndole con lo que sea necesario á su instrucción, y proporcione generosidad de los pudientes, de aquellos ricos que aunque gozan de mejor fortuna; no obstante son, como ellos, hijos de una misma madre, la Patria, miembros de un mismo cuerpo, el Estado, y sujetos igualmente a aquella ley que declara indigno de la sociedad y desnaturalizado al que haciéndose sordo á los clamores de la naturaleza, y olvidándose de la fidelidad que prometió al jurar ser cristiano; abre las puertas de su corazón a un egoísmo que le acrimina ante Dios y los hombres ${ }^{106}$.

21 La Academia apenas estuvo abierta un año, pues la epidemia de fiebre amarilla de finales de verano de 1821 y la muerte de su director obligaron a cerrarla. Posteriormente hubo algunos intentos de reabrirla, pero al situar al frente de esta al liberal moderado Manuel Casamada, provocó que los gobiernos exaltados municipales se negaran a financiarla, a pesar de las demandas de insignes líderes del liberalismo mayoritariamente moderado y algunas voces exaltadas que querían restablecer la formación política en la Academia, siguiendo los criterios de J. Catalá107. La radicalización de la ciudad abortó aquel debate y la Academia se dedicó exclusivamente a la formación de ciegos y sordos que había iniciado con la llegada a la dirección de Casamada ${ }^{108}$.

De todos modos, esta no fue la única iniciativa para limitar su desarrollo revolucionario. Así, en los meses de vida de la MNV en algunas localidades como Zamora o Salamanca ${ }^{109}$ se alistaron numerosos contrarios al régimen liberal para controlar, obstaculizar o desestabilizar el funcionamiento de la milicia. En otras localidades se prefirió extender el miedo de un posible enfrentamiento entre el ejército y la MNV, como ocurrió en Barcelona. Para los liberales exaltados, el ejército estaba directamente controlado por el ejecutivo, mientras que la MNV se amparaba en el reglamento que emanaba del poder legislativo ${ }^{110}$, aunque en última instancia estaban bajo el control del jefe político de la provincia. Por otro lado, la autonomía de la MNV hizo que los ayuntamientos favorecieran la creación de batallones con milicianos disidentes de otros cuerpos, como ocurrió en Cádiz o Barcelona. En Barcelona se formó el cuarto batallón a partir de los disidentes del tercero, el sexto batallón mediante los disidentes del quinto, y el cuerpo de artillería con los disidentes del primer regimiento de la $\mathrm{MN}^{111}$ después del conflicto que enfrentó al primer regimiento con el ayuntamiento, convirtiendo a los nuevos batallones en un contrapoder.

El jefe político de Barcelona, Vicente Sancho, quien había sido uno de los principales valedores en las Cortes del ejército mixto con una numerosa presencia de la $\mathrm{MN}^{112}$, ordenó prohibir las reuniones de MN sin su autorización previa ${ }^{113}$, dada la vinculación de aquellas con las filas del liberalismo exaltado. El ayuntamiento de la ciudad también impuso medidas para represaliar a los milicianos más revolucionarios, ordenando que se expulsara a aquellos que habían participado en los tumultos ocurridos en la ciudad entre febrero y junio de 1822. También fueron expulsados aquellos que no cumplieran con el reglamento o aquellos que «carecieran de las circunstancias que previene el reglamento ${ }^{114}$ », lo que demuestra la poca atención que se había tenido hasta aquel momento en el cumplimiento del reglamento. La purga de la MN no fue exclusiva de Barcelona, sino que fue una práctica recurrente: en Alicante se purgó a los jornaleros 
alistados a la MNV, aplicándoles estrictamente el reglamento de agosto de 1820 que les excluía. Con aquella purga, como apuntan Gutiérrez y Zurita, se quería evitar la radicalización del cuerpo, lo que significó una reducción de milicianos casi a la mitad, restructurándose la MNV, con lo que pasó de 4 a 2 batallones ${ }^{115}$. En Zamora se aseveró que algunos milicianos habían participado en altercados en la ciudad, ${ }^{116}$ pero fue el fallido golpe de los reaccionarios en Madrid, el 7 de julio de 1822, el que potenció si cabe las medidas represivas y adoctrinadoras de las MN, como apunta Codesal ${ }^{117}$. Todas aquellas medidas surgieron efecto al reducir y dividir la acción de la MN, pero no consiguieron impedir que esta jugara un papel fundamental para que los exaltados alcanzaran el control de las instituciones. Aun así, esto no significó que se acabaran los intentos de controlar, limitar y debilitar la MN, que también se erigió en una amenaza para los exaltados.

El control sobre los batallones de la MN siempre estuvo en el punto de mira de ayuntamientos y diputaciones, produciéndose recurrentes enfrentamientos entre ellas a partir del otoño de 1822. El municipio solía estar en manos de los sectores exaltados y de los jefes políticos que controlaban las diputaciones, que representaban opciones más moderadas, como ocurrió en Barcelona, Almería, Madrid o Cádiz ${ }^{118}$. En ciudades como Zamora $^{119}$ o Salamanca ${ }^{120}$ ocurrió todo lo contrario, pues el ayuntamiento optó por una línea moderada mientras la diputación lideraba una propuesta más exaltada que pretendía incrementar los recursos y el número de milicianos, ofreciéndoles recompensas posteriores en su ingreso al ejército o en la administración ${ }^{121}$. Las pugnas entre las instituciones revelan cómo la MN ejercía de auténtico contrapoder institucional, y cuando se decantaba por una u otra institución rompía el equilibrio institucional definido por la Constitución, encumbrando al poder al liberalismo exaltado o al radical.

La MN se convirtió en la única institución capaz de preservar la autonomía del liberalismo revolucionario, a pesar de los intentos por controlar, dirigir, purgar o educar a los milicianos que no tuvieron un efecto distinto en función de la capacidad movilizadora de la MN en cada localidad. Desde el primer momento, ayuntamientos y diputaciones trataron de limitar la incidencia de la MN en la vida política local, pero en la medida que aumentaron los enfrentamientos entre liberales moderados y exaltados la MN se convirtió en un órgano fundamental para proyectar el insurreccionalismo liberal de las calles a las instituciones a través de la movilización popular, lo que multiplicó la incidencia de las clases populares y medias en la política liberal. Las autoridades liberales solo consiguieron acotar la capacidad revolucionaria de la MN allí donde la iniciativa de crearla fue tardía e instigada por las instituciones locales, que retrasaron su formación para beneficiarse de la modificación reglamentaria. Cuando no fue así, ayuntamientos y diputaciones impulsaron iniciativas para limitar su potencial revolucionario y ejercer un mayor control, lo que tuvo el éxito esperado en la medida que el liberalismo exaltado consiguió el poder local y provincial con el apoyo de la MN. Una vez en el poder el liberalismo exaltado solo consiguió limitar el poder de la MN puesto que pudo sacarla de las ciudades para que combatiera a los rebeldes realistas, encuadrando a los batallones de la MNV en la Milicia Nacional Activa (MNA) que organizaba columnas expedicionarias para combatir a los insurrectos fuera de la provincia. 


\section{La Milicia Nacional en guerra: la proliferación de batallones}

La reforma del reglamento de la MN se aprobó el 29 de junio de 1822 y, como apuntan Pérez Garzón y Gil Novales, el reglamento reforzaba la división de la MN en Voluntaria y Legal con el fin de contrarrestar el carácter democrático de la primera, introduciendo la tutela gubernativa a través de la segunda ${ }^{122}$. La obligatoriedad de la MN se extendía y para su organización se creaban nuevos cuerpos como la caballería y la artillería, que hasta ese momento solo existían en algunas ciudades como Cádiz o Barcelona que tenían una larga tradición de milicias locales para defenderse de los asedios. La gestión de la financiación de la MN recaía en los ayuntamientos, aunque dependían políticamente del jefe político de cada provincia, mientras la diputación se encargaba del cumplimiento de las ordenanzas y los ayuntamientos de la organización interna ${ }^{123}$. El reglamento también preveía la formación de compañías de cazadores que se ocuparían de vigilar los caminos y carreteras, que en opinión de Pérez Garzón ${ }^{124}$ se convertiría así en una guardia rural, aunque Calles prefiere definirla como una milicia mercenaria por la retribución de las unidades que desempeñaban la función de defender la provincia ${ }^{125}$. Así, en las provincias se constituyeron unidades específicas. En Salamanca, a finales de 1822, se formaron las compañías de Cazadores Volantes de la Constitución y de Lanceros de la Constitución con la finalidad de perseguir y derrotar a los realistas en la provincia ${ }^{126}$, distinguiéndolas de la MNA. En Zaragoza también se constituyeron tres compañías de Cazadores Voluntarios de 100 milicianos cada una, en agosto de 1822, con el fin de combatir a los realistas en los pueblos de la provincia, que popularmente fueron conocidos como peseteros ${ }^{127}$, a raíz de la retribución que obtenían por sus acciones. La disolución de la columna expedicionaria comandada por J. Costa provocó que parte de aquellos milicianos formaran el batallón de Cazadores de la Provincia que se integró en el ejército comandado por el general F. Espoz y Mina ${ }^{128}$. Aquellas unidades de Cazadores se destinaron a la defensa del régimen liberal, pero eran comandadas por la autoridad militar.

La guerra contra los insurrectos realistas desde la primavera de 1822 y posteriormente contra los Cien Mil Hijos de San Luis trasladó el esfuerzo liberal a defender el régimen político, y la MN se convirtió en su principal defensor, sobre todo después de que la MNV de Madrid abortara el golpe militar de la Guardia Real el 7 de julio de 1822. La organización de la resistencia contra los enemigos interiores y exteriores hizo que proliferaran el número de batallones en los que se encuadraron aquellos que hasta ese momento no habían sido alistados. Aumentaron así el número de batallones de la MNL y de la MNV También se crearon las columnas móviles de MNA que se unían a las tropas regulares y se desplazaba desde distintas localidades para combatir a los realistas. La MN rebasó los límites del marco reglamentario y favoreció que concurrieran en sus filas individuos que estaban implícita o explícitamente excluidos de la MN. Por lo tanto, aquel proceso de crecimiento de la MN que a menudo ha sido menoscabado por la apatía y el poco compromiso de los milicianos debería revisarse, pues no sucedió así en todos los territorios. La formación de aquellos cuerpos de milicianos reflejaba la necesidad de ampliar la condición de ciudadano con el fin de sumar apoyos contra los enemigos del régimen. Prueba de ello fue el llamamiento que hizo el «Regañón T.B.» (Tomás Bruguera) para incrementar el número milicianos: 
Decidámonos pues: muévanos el ejemplo de tanto jornalero que no teniendo de que comer el día que no trabaja, ha sabido, sin embargo, ser superior al dominio de su suerte, alistándose voluntariamente ya desde el principio para la formación de los beneméritos batallones que tanto bien han tributado a la patria. ${ }^{129}$

Aquellos llamamientos y el desplazamiento de milicianos desde localidades en manos de las tropas francesas y realistas hicieron que el nombre de milicianos aumentara. A continuación, detallamos los cuerpos de milicianos que se constituyeron más allá de los reglamentos de la MN, lo que demuestra cómo la MN se consolidó como una vía de acceso a la ciudadanía más allá del marco constitucional.

29 1) En primer lugar, hubo la formación de columnas expedicionarias de milicianos, denominadas MNA, que servían fuera de su localidad y en ocasiones de su provincia. Aquellas unidades se crearon para combatir las partidas de realistas que se enfrentaban al régimen liberal. La amenaza realista no solo se extendió por el norte y centro de la península, sino también por la costa mediterránea, proliferando las partidas realistas, lo que significó que se formaran columnas de la MNA en distintas provincias como Cádiz, Málaga, Almería, Guipúzcoa, Salamanca o Barcelona. Una de las cuestiones más relevantes de las columnas expedicionarias era su inusitada capacidad política. Así, cuando la diputación de Barcelona aprobó un plan para organizar la defensa de la provincia previó que las fuerzas milicianas de cada partido estuvieran dirigidas por los «comandantes de armas», que tendrían la capacidad de vigilar el comportamiento de párrocos y ayuntamientos, estando facultados para imponer multas si no cumplían con sus deberes. También podían nombrar comisiones de vigilancia en los pueblos que lo creyesen conveniente si sus autoridades políticas y eclesiásticas no actuaban de acuerdo a los principios constitucionales, lo que facultaba a estas autoridades milicianas a tener una capacidad política represiva bajo el amparo en última instancia de la diputación ${ }^{130}$.

Posiblemente la MNA más popular y populosa fue la División Expedicionaria, conocida como la Columna del coronel Josep Costa, que se concibió como un cuerpo miliciano que integraba distintas unidades procedentes de la MNV de Barcelona, milicianos del partido judicial de Barcelona, milicianos de caballería, expatriados y civiles organizados como migueletes ${ }^{131}$. El cuerpo debía alcanzar los dos mil hombres ${ }^{132}$, aunque los datos de Dueñas apuntan que no llegó a superar los 1.300. Todos ellos se organizaron en tres batallones de MNV (1 $1^{\circ}$ Soberanía Nacional; $2^{\circ}$ Libertad; y $3^{\circ}$ Igualdad), una unidad de MN de partido, unidad de menorquines i mallorquines que habían solicitado trasladarse a Cataluña para defender el régimen liberal y unidad de italianos ${ }^{133}$. Varios estudios se han dedicado a analizar la sociología y comportamiento del Batallón de emigrados italianos ${ }^{134}$ que alcanzó un total de 283 individuos ${ }^{135}$. La historiografía se ha ocupado profusamente de las unidades conformadas por expatriados fundadas en otros territorios como La Coruña y el País Vasco, como el Régiment de Napoléon II o los Lanciers français défenseurs de la Liberté ${ }^{136}$ y que a partir de abril de 1823 se integraron bajo el nombre la Legión Liberal Extranjera ${ }^{137}$, aprobada por las Cortes para defender la España constitucional. También cabe señalar el intento de constituir una Legión Europea, liderada por el general inglés Robert Wilson, el comandante británico Briston y el general francés Lallemand. La legión debía estar integrada por cinco mil hombres procedentes de Inglaterra y Francia, pero aquella idea no pudo llegar a materializarse ${ }^{138}$. Sin embargo, el estudio sobre las unidades formadas por expatriados demuestra que solo el Batallón de emigrados italianos se integró en una columna de la 
MNA, mientras la Legión Liberal Extranjera formada por unidades de franceses e italianos, lo hizo en el ejército regular. La más conocida de aquellas unidades fue el llamado Bataillon de Napoléon II que actuó en Vizcaya.

2) En segundo lugar, se organizaron distintos batallones de profesores y alumnos, también conocidos como «literarios» y que integraban a estudiantes universitarios, que se formaban en Barcelona con el fin de acabar con la exención que preveía el reglamento de la MNL. El batallón se constituyó a principios de 1823 al mismo tiempo que se formaba en Barcelona el «Batallón de profesores y alumnos del arte de curar». Ambos batallones conectaban con una antigua tradición que se remontaba a los asedios que sufrió la ciudad durante el siglo XVII y XVIII, cuando se constituyeron batallones de profesores y de alumnos para defender la ciudad. En otras localidades como Santiago de Compostela se instituyó una ceremonia que rememoraba el batallón literario formado en 1808 durante la Guerra de la Independencia, aunque no se formara de nuevo ${ }^{139}$. Tampoco se pudo formar en Salamanca, donde las autoridades liberales rechazaron las peticiones de numerosos estudiantes de conformar una unidad de milicianos, que se incorporarían a las filas de la milicia local al terminar el curso ${ }^{140}$. No obstante, a principios de 1823 se formó la compañía de artillería asegurándose que la mitad de esta estaba integrada por estudiantes ${ }^{141}$. También rechazaron la posibilidad de establecer un batallón específico para la atención médica y el cuerpo médico se integró al primer batallón de la MNV de Salamanca ${ }^{142}$.

32 3) En tercer lugar, se constituyó en Barcelona en mayo de $1823^{143}$ la compañía de zapadores-bomberos, siguiendo el modelo napoleónico de París en el que un batallón de zapadores de la Garde Impériale se convirtió en el moderno cuerpo militarizado de bomberos de París, que no formaría parte de la Garde Nationale hasta 1831. Este batallón se volvió a conformar en Barcelona la década siguiente, en 1836 después del incendio de los conventos, pero en contra de lo que se pudiera creer se convirtió en un referente político progresista, lo que le valió ser represaliado en 1837.

4) En cuarto lugar se formaron los batallones de los ciudadanos que hasta ese momento estaban exentos del servicio en la MNV e integraban la reserva voluntaria o en reserva de los estudios. Se formó en Barcelona un «batallón de mayores de 45 años, de empleados públicos y ciudadanos con defectos físicos» ${ }^{144}$, y en San Sebastián otro de «ciudadanos honrados y respetables por su edad» ${ }^{145}$. Con ellos se intentaba convertir el conflicto contra los realistas en una suerte de guerra total, por lo que se formaron a principios de 1823 cuando la amenaza de la invasión de las tropas francesas era muy presente.

5) En quinto lugar, desde principios de 1821 se habían empezado a fundar los batallones gimnásticos-militares o cuerpos patrióticos juveniles de la MN para niños de 7 a 16 años, en ciudades como Barcelona, Zaragoza ${ }^{146}$, Palma y probablemente Madrid, en que intervinieron un grupo de niños vestidos de milicianos en la Tertulia Patriótica Landaburiana durante siete días de mediados del mes de noviembre de $1822^{147}$. En Barcelona aquel batallón llegó a encuadrar a más de cien jóvenes que participaron en algunas festividades o ceremoniales vinculados a la fortificación de la ciudad en verano de $1823^{148}$. El batallón barcelonés se constituyó en junio de 1821 y en él se impartían lecciones de matemáticas, de historia nacional en clave liberal, de los principios y elementos constitucionales, y de gimnasia. Los niños y chicos del batallón procedían de distintos grupos sociales y el coste de su vestuario estaba en función de su procedencia social, por lo que las suscripciones y donativos que recibía el batallón se dedicaban 
mayoritariamente a cubrir los gastos derivados del coste de los uniformes y materiales destinados a los hijos de los artesanos ${ }^{149}$. El batallón era una expresión más de la voluntad de educar y formar políticamente a los jóvenes e impedir que vaguearan por la ciudad. Aquella preocupación había existido desde el momento en que triunfó el régimen constitucional, pues los liberales tenían la convicción de que solo la educación podría convertir a los niños en futuros ciudadanos liberales. Prueba de ello es la preocupación y los recursos que destinaron a alfabetizar y dar las primeras nociones a los niños con menos recursos. Detrás de aquellos batallones había un proyecto educativo desvinculado del control eclesiástico que estará en el origen de las escuelas municipales gratuitas de 1841 .

La falta de instrucción para la clase de jornaleros, especialmente los trabajadores de fábrica, se hace cada día mas sensible. Ocupados sus hijos todo el día en ganar un escaso jornal no puede asistir a las escuelas gratuitas: por lo que penetrado de sensibilidad por una clase tan numerosa como útil, un ciudadano dedicado a la primera educación de algunos años a esta parte, se ofrece a admitir hasta el núm. de 30 niños del indicado ramo, de la edad de 5 a 10 años, a fin de enseñarles á leer y escribir y los primeros elementos de aritmética, que es lo que indispensablemente necesita un hombre para disfrutar de los derechos de ciudadano (...) se darán lecciones de 6 a 8 de la noche (...). El amante de los pobres, J. Domenech ${ }^{150}$. La finalidad de aquellos batallones era que los niños recibieran una educación patriótica y constitucional, aunque el reglamento del batallón de Barcelona ${ }^{151}$ destacaba que a través de los niños se podría educar a las madres en los principios del liberalismo al tener limitada su participación en los espacios usuales de formación política: cátedras constitucionales, gabinetes de lectura, sociedades patrióticas, etc. A partir de otoño de 1822 aquello cambió sustancialmente a raíz de la mayor permisividad gubernamental con la fundación y las reuniones de Sociedades y Tertulias Patrióticas, lo que explica la presencia entre el público de mujeres, su participación como oradores o hasta que presidieran algunas sesiones, como ocurrió en Barcelona, Madrid, Cádiz, Sevilla, San Sebastián o Valencia. Aquella situación de flexibilidad y permisividad en las sociedades patrióticas favoreció una iniciativa sin parangón en el resto de la monarquía, la formación de un batallón de milicianas en Barcelona.

6) En sexto lugar se organizó el batallón de milicianas que lideró y dirigió la viuda del general mártir Luis Lacy. Aunque fue el único batallón formado íntegramente por mujeres durante el Trienio, su eco fue tan relevante que durante la Guerra Carlista (1833-1840) se formaron batallones similares en otros lugares de Castilla y el País Vasco ${ }^{152}$. La idea de formar un batallón de milicianas se fraguó en la Tertulia Patriótica de Lacy, lo que derivó en la fundación de una sociedad patriótica de milicianas barcelonesas. El jefe político, Fernando Gómez de Butrón, autorizó la existencia de aquella agrupación, regulando sus reuniones y acotando sus funciones, lo que la desnaturalizó y redujo su capacidad y autonomía política. Emilia du Guermeur era la directora de la sociedad y con la radicalización de la ciudad en el verano de 1823 vio una oportunidad, reconoció con celeridad la autoridad al exaltado de Antoine Rotten y puso a su disposición a las ciudadanas de la sociedad para que trabajasen en la fortificación de los fuertes de la muralla. Rotten aceptó y las ciudadanas de la sociedad recuperaron la denominación popular de milicianas, rompiendo una vez más los límites fijados por el reglamento y por el anterior jefe político ${ }^{153}$. 
Aquellas ciudadanas, como comentaba la prensa, no se contentaban con auxiliar a los heridos «sino que quieren acompañarnos en los peligros, y prestarlos en el mismo acto de una acción, exponiéndose a derramar también la sangre» ${ }^{154}$. En aquellas semanas se grabaron distintas imágenes de milicianas en formación empuñando sus lanzas, custodiando el baluarte, curando heridos, hablando con los milicianos, debatiendo entre ellas y leyendo la prensa. Todas aquellas acciones denotaban el reconocimiento implícito de una igualdad civil y el reconocimiento de sus derechos políticos, basándose en su capacidad de formar parte del pueblo en armas, de participar en la conformación de la opinión pública y de garantizarse los derechos reconocidos a los ciudadanos por la Constitución. Apenas un mes antes de que la ciudad se rindiera a las tropas francesas, en septiembre de 1823 se constituyó un nuevo batallón de ciudadanos no aptos para el servicio militar para que se encargaran de recoger a los heridos en combate dentro y fuera de la ciudad, batallón de «la unión y caridad» ${ }^{155}$, lo que significó el fin de la autonomía del batallón de milicianas, que quedó bajo el control del nuevo batallón.

Los datos reflejan cómo gradualmente, en tres fases, se produjo un incremento del número de batallones: primera, durante 1820 se constituyeron los batallones de la MNV y el cuerpo de caballería; segunda, en la primavera de 1822 se formaron los batallones de la MNL y el cuerpo de artillería; y la tercera, a partir de finales de verano de 1822 se constituyeron la mayoría de los batallones especiales y el cuerpo de zapadores. La periodización de la formación de las unidades de la milicia demuestra un doble proceso: por una parte, la voluntad de debilitar la MNV creando nuevos batallones que se conformaban a partir de escisiones moderadas de unidades precedentes; y por la otra, la formación de batallones durante los gobiernos exaltados en los que se alistaban ciudadanos excluidos por los reglamentos, abriéndose la puerta de los derechos de ciudadanía a mujeres, extranjeros, artesanos pobres, jornaleros del campo y de las fábricas. También se fomentó el espíritu público a través de la formación de unidades de niños y jóvenes más pensadas en educarlos políticamente y acceder a sus madres, cuando resultaba difícil movilizar a las mujeres. La resistencia de Barcelona mostró por un lado la movilización de las clases populares en defensa del régimen liberal y por el otro, el triunfo de la sumisión de la milicia a la autoridad militar de la provincia, que no supo aprovechar el entusiasmo patriótico de los milicianos y estuvo más preocupado en evitar que se erigieran en una fuerza revolucionaria capaz de desafiar a las autoridades, liderando la lucha contra el enemigo realista.

El creciente número de batallones especiales esbozó cómo la ciudad liberal acosada por el invasor requería de un elenco de unidades que cubriesen las necesidades de la ciudadanía, como era la atención y cura de los heridos, y la lucha contra los incendios, más allá del control del orden público y de la formación de los ciudadanos. Aquellos batallones también representaban la movilización de casi todo el conjunto de la sociedad barcelonesa, en particular de los excluidos de la MN como habían sido mujeres, gente mayor, jóvenes, jornaleros, pobres, estudiantes o profesores. La MN adquirió una nueva función cívica: la defensa frente a los enemigos internos y externos a la patria, que completaban las demás: la de control del orden público, la representación del triunfo de la política con una amplia base popular, y la de vigilancia y fiscalización del gobierno y las instituciones liberales. El modelo de MN de Barcelona no puede extrapolarse al conjunto de ciudades españolas, aunque tenemos indicios de ciertas similitudes con otras ciudades liberales. La trascendencia de la MN en Barcelona se fundamentó en el número, diversidad y especificidad de batallones, lo que facilitó la 
movilización de colectivos sociales que estaban marginados por los reglamentos. La organización, funcionalidad y actividad de los batallones corrobora que la MN se erigió en el principal espacio de aprendizaje de la política liberal durante el Trienio, vehiculando identidades políticas basadas en la exaltación del pueblo y la revolución.

\section{Conclusiones}

La historiografía ha debatido sobre el impacto de la MN. Mientras Blanco Valdés afirma que el alistamiento fue muy pobre al no cumplirse el reglamento, Rodrigo Moreno considera más relevante el efecto que tuvo la propaganda trasladada desde España a Nueva España ${ }^{156}$ y resalta la importancia de la MN para la defensa de la Constitución y de los derechos del ciudadano. Con ello Moreno confirma la tesis de Fuentes, basada en la parte europea de la monarquía, que considera que la MN durante el Trienio Liberal vivió su edad de oro y la define «como la institución más genuina y representativa del liberalismo español» ${ }^{157}$. Moreno apunta diferencias significativas respecto a la adaptación que se hizo del nuevo reglamento en América donde no se universalizó el alistamiento, lo que impidió que se convirtiera en el gran contrapeso nacional que hubieran querido los liberales. Aun así, algunos historiadores como Sergio Paolo Solano discrepan con esta interpretación al considerar que el liberalismo, en determinados territorios como el caribe colombiano, ofreció un lenguaje moderno y un contexto favorable para proyectar las aspiraciones políticas de «los hombres libres de color» ${ }^{158}$.

41 La tendencia de la historiografía ha sido interpretar el éxito o fracaso de la MN a partir de su capacidad de reclutar o alistar ciudadanos desde una perspectiva nacional, olvidándose del efecto político que tuvo la MN en el territorio. Esta investigación pone de relieve la relevancia del espacio local en el desarrollo político de la MN, pues se convirtió en una organización fundamental para entender el arraigo del liberalismo y su dimensión revolucionaria. El texto ha concentrado su atención en las ciudades que tuvieron una trayectoria ineludiblemente liberal, decantándose a partir del verano de 1822 hacia posiciones exaltadas, lo que ha permitido observar cómo la MN fortaleció el poder de las autoridades exaltadas.

La MN se convirtió en la única organización capaz de preservar el liberalismo revolucionario de la deriva moderada de los primeros años del Trienio, lo que permitió a los liberales exaltados recurrir a la movilización popular para auparse al poder institucional. Los reiterados intentos de las instituciones locales y provinciales de debilitar la autonomía de la MN fueron estériles en la medida que en las principales ciudades liberales se erigieron como el mayor contrapoder institucional, basándose en su representatividad popular y capacidad movilizadora. La MN consiguió organizar un colectivo social capaz de influir en política en la medida que otorgaba un significado propio a la política liberal, fundamentado en la supremacía de la voluntad popular en detrimento del texto constitucional, lo que les proyectaba su acción política hacia horizontes insurreccionales. Su éxito debería mesurarse en la capacidad que tuvo de incidir en la política local y nacional, derribando gobiernos y limitando la acción de los municipios y jefes políticos provinciales, aunque también debería tenerse en cuenta que la proliferación de batallones de la MN estuvo en el origen de la gestión de algunos servicios municipales dedicados a la educación, protección y cuidado de la ciudadanía, lo que favoreció que los principios revolucionarios del liberalismo llegaran hasta colectivos sociales excluidos de la condición de ciudadano por la norma constitucional. 
Aquello convirtió la MN en uno de los motores de la revolución al proyectarse más allá de la Constitución, erigiéndose en el arma más eficaz para que los ciudadanos vigilaran las instituciones liberales.

Por otro lado, el liberalismo revolucionario se convenció de que la única garantía de acceder al poder en el futuro era contar con el apoyo de las clases populares, y el Trienio resultó una suerte de aprendizaje político para ver de qué forma se podía conseguir el poder institucional desde la movilización de la calle. Todas las revueltas posteriores de los liberales tendrán en cuenta la necesidad de contar con el apoyo de una milicia o de parte de ella para presionar a las instituciones y alzarse con el poder político. La MN puso los cimientos de la organización de las clases populares y medias de las ciudades, determinando el ritmo político de las ciudades que lideraron la revolución liberal en las dos décadas posteriores.

\section{NOTAS}

1. Roberto L. Blanco Valdés, Rey, Cortes y fuerza armada en los orígenes de la España Liberal, 1808-1823, Madrid, Siglo XXI-Ed. Alfons el Magnànim, 1988.

2. Juan Sisinio Pérez Garzón, Milicia Nacional y revolución burguesa. El prototipo madrileño. 1808-1874, Madrid, Alianza,1978.

3. Claudio Calles Hernández, La Milicia Nacional en Salamanca durante el Trienio Liberal (1820-1823), Salamanca, Universidad de Salamanca, 2015.

4. José María García León, La Milicia Nacional en Cádiz durante el Trienio Liberal (1820-1823), Cádiz, Caja de Ahorros, 1983.

5. José Fermín Garralda Arizcun, «La Milicia Nacional de Pamplona durante el Trienio Constitucional. Estudio sociológico y político de sus componentes», Príncipe de Viana. Anejos, no 9, 1988, p. 319-334.

6. Óscar González García, «Hechos de la milicia nacional leonesa, 1820-1823», Paulino Castañeda Delgado (coord.), Las guerras en el primer tercio del siglo XIX en España y América; Actas XII Jornadas Nacionales de Historia Militar, Sevilla, Cátedra general Castaños, Deimos, 2006.

7. Francisco Dueñas, La Milicia Nacional en Barcelona durante el Trienio Liberal, 1820-1823, Tesis Doctoral, Bellaterra, Universitat Autònoma de Barcelona, 1997.

8. Rosa Ana Gutiérrez Lloret y Rafael Zurita Aldeguer, «El Trienio Constitucional y la organización de la Milicia Nacional en Alicante», En La revolució francesa i el procés revolucionari a Catalunya i al País Valencià, Bellaterra, Colloqui Internacional de Girona, 1990, p. 99-114.

9. Antoni Sánchez Carcelén, «La Milícia Nacional de Lleida al Trienni Liberal», Revista HMiC, n 5, 2007, 195-219, seneca.uab.es/hmic/index.html, última consulta, 05/07/2018; y Antoni Sánchez Carcelén, «La formación de la Milicia Nacional en Lleida (1820-1821)», Cuadernos de Historia Contemporánea, 2009, vol. 30, p. 251-271. 
10. Quintí Casals, «Milicia Nacional, liberalismo y progresismo. El prototipo leridano en los primeros dos tercios del siglo XIX», Trienio: Ilustración y Romanticismo, nº 35, mayo 2000, p. 117-154.

11. Ramon Vallverdú, La milicia nacional en Reus en els orígens de la Catalunya isabelina, Tarragona, Institut d'Estudis Tarraconenses, 1986; y Ramon Vallverdú, El suport de la Milícia Nacional a la revolució burgesa a Reus (1793-1876), Reus, Associació d'Estudis Reusencs, 1989.

12. Miguel Naranjo Sanguino, La Milicia Nacional de la ciudad de Badajoz y su marco provincial hasta la disolución de 1844, Badajoz, Diputación Provincial, 2008.

13. Matilde Codesal Pérez, La ciudad de Zamora en el Trienio Liberal (1820-1823): Conflictividad sociopolítica en un contexto de crisis, Zamora, Ayuntamiento-UNED, 2008.

14. Antonio Guillén Gómez, Una aproximación al Trienio Liberal en Almería: La Milicia Nacional Voluntaria y su entorno (1820-1823), Almería, Instituto de Estudios Almerienses, 2000.

15. María Teresa Garabain Aranguren, «Los Orígenes del Liberalismo en Rentería», Bilduma Rentería, no 6, 1992, p. 9-82.

16. Lara Martín-Portugués, Jaén (1820-1823). La lucha por la libertad durante el Trienio Liberal, Jaén, Ayuntamiento, 1996.

17. Luis Sorando Muzás y Antonio Manzano Lahoz, «La Milicia Nacional en Zaragoza (1820-1823)», Emblemata, ํㅜㄴ 6, 2000, p. 177-212.

18. Pedro Rújula López, Constitución o muerte. El Trienio Liberal y los movimientos realistas en Aragón (1820-1823), Zaragoza, Pub. Rolde de Estudios Aragoneses, 2000.

19. Ramon Arnabat, La revolució de 1820 i el Trienni Liberal a Catalunya, Vic, Eumo, 2001.

20. Félix Llanos Aramburu, El Trienio Liberal en Guipúzcoa (1820-1823). Antecedentes de las Guerras Carlistas en el País Vasco, San Sebastián, Universidad de Deusto, 1998.

21. Vicente Fernández Benítez, Carlismo y rebeldía campesina. Un estudio sobre la conflictividad social en Cantabria durante la crisis final del Antiguo Régimen, Madrid, Siglo XXI-Ayuntamiento de Torrelavega, 1988.

22. Xosé Ramón Veiga, «La Milicia Nacional como espacio de politización liberal en Galicia (1820-1844)», Old and New Worlds: the Global Challenges of Rural History, Conferencia Internacional, Lisboa, ISCTE-IUL, 2016, última visita, 07/07/2018, https:// lisbon2016rh.files.wordpress.com/2015/12/0026-onw1.pdf

23. Antonio Mejide Pardo, «Guerra Civil de 1823: intervención del general inglés Wilson en ayuda de la Galicia liberal», Anuario Brigantino, no 26, 2003, p. 237-252.

24. Valentí Valenciano, El Trienni Liberal a Mallorca, 1820-1823, Tesis Doctoral, Mallorca, Universitat de les Illes Balears, 2012.

25. Juan Díaz-Pintado, Revolución Liberal y Neoabsolutismo en la Mancha (1820-1833): Manuel Adame, El Locho, Ciudad Real, Diputación, 1998.

26. Manuel Chust, Ciudadanos en armas. La Milicia Nacional en el País Valenciano, Valencia, Ed. Alfons el Magnànim, 1987.

27. Juan Francisco Fuentes, «Milicia Nacional», en Javier Fernández Sebastián y Juan F. Fuentes (eds.), Diccionario político y social del siglo XIX español, Madrid, Alianza Editorial, 1999, p. 443.

28. Alberto Gil Novales, Las sociedades patrióticas (1820-1823): las libertades de expresión y de reunión en el origen de los partidos políticos, Madrid, Tecnos, 1975, p. 59-60.

29. Roger Dupuy, La Garde nationale: du déni historiographique à la nécessité d'un nouveau questionnement, Serge Bianchi y Roger Dupuy (dir.), La Garde nationale entre Nation et 
peuple en armes: Mythes et réalités, 1789-1871, Rennes, Presses universitaires de Rennes, 2006, última visita 07/07/2018, http://books.openedition.org.sabidi.urv.cat/pur/16598, DOI: 10.4000/books.pur.16598; y Roger Dupuy, La Garde nationale 1789-1872, París, Gallimard, 2010.

30. Louis Girard, La Garde nationale, 1814-1871, Paris, Plon, 1964.

31. Georges Carrot, La Garde nationale (1789-1871), Une force politique ambiguë, Paris, L'Harmattan, 2001.

32. A. Gil Novales, Las sociedades patrióticas..., op. cit., p. 61.

33. J. Mª. García León, La Milicia Nacional en Cádiz..., op. cit., p. 42.

34. R. Arnabat, La revolució de 1820..., op. cit., p. 114.

35. A. Guillén, Una aproximación al Trienio..., op. cit., p. 68.

36. C. Calles, La Milicia..., op. cit., p. 44-45.

37. O. González García, «Hechos de la..., op. cit., p. 20.

38. M. Codesal, La ciudad de Zamora..., p. 157-161.

39. F. Llanos, El Trienio Liberal en Guipúzcoa..., op. cit., p. 160.

40. V. Valenciano, El Trienni Liberal..., op. cit., p. 185.

41. R. Arnabat, La revolució de 1820..., op. cit., p. 115.

42. A. Sánchez Carcelén, «La Milícia Nacional..., op. cit., p. 198.

43. F. Llanos, El Trienio Liberal en Guipúzcoa..., op. cit., p. 161.

44. V. Fernández Benítez, Carlismo..., op. cit., p. 153 y A. Gil Novales, Las sociedades patrióticas..., op. cit., p. 146.

45. V. Valenciano, El Trienni Liberal..., op. cit., p. 430.

46. A. Gil Novales, Las sociedades patrióticas..., op. cit., p. 512.

47. C. Calles, La Milicia..., op. cit., p. 126.

48. C. Calles, La Milicia..., op. cit., p. 97 y 328.

49. J. Mª. García León, La Milicia Nacional en Cádiz..., op. cit., p. 46.

50. M. Codesal, La ciudad de Zamora..., op. cit., p. 188.

51. J. S. Pérez Garzón, Milicia Nacional..., op. cit., p. 111.

52. J. F. Fuentes, «Milicia Nacional»..., op. cit., p. 445.

53. R. Arnabat, La revolució de 1820..., op. cit., p. 126.

54. C. Calles, La Milicia..., op. cit., p. 60.

55. J. F. Garralda, «La Milicia Nacional de Pamplona..., op. cit., p. 332.

56. M. Codesal, La ciudad de Zamora..., op. cit., p. 158.

57. M. Codesal, La ciudad de Zamora..., op. cit., p. 186-187.

58. C. Calles, La Milicia..., op. cit., p. 70.

59. F. Dueñas, La Milicia Nacional..., vol. 1, op. cit., p. 262.

60. R. Arnabat, La revolució de 1820..., op. cit., p. 118.

61. R. Vallverdú, El suport..., op. cit., p. 166.

62. A. Sánchez Carcelén, «La Milícia Nacional..., op. cit., p. 211.

63. R. Arnabat, La revolució de 1820 ..., op. cit., p. 117.

64. José de Orga, Apuntes históricos de la milicia nacional de Valencia, desde su creación en el año de 1820 hasta 1823, Valencia, Librerías París-Valencia, 1855.

65. M. R. Gutiérrez y R. Zurita, «El Trienio Constitucional..., op. cit., p. 103.

66. L. Sorando y A. Manzano, «La Milicia Nacional..., op. cit., p. 185.

67. M. Codesal, La ciudad de Zamora..., op. cit., p. 181.

68. C. Calles, La Milicia..., op. cit., p. 325.

69. O. González García, «Hechos de la..., op. cit., p. 7-8.

70. V. Valenciano, El Trienni Liberal..., op. cit., p. 185.

71. R. Arnabat, La revolució de 1820..., op. cit., p. 118. 
72. Antonio de Anta Muñoz, La Diputación provincial de Valladolid, en el siglo XIX (1813-1874), Valladolid, Tesis Doctoral, Universidad de Valladolid, 2012, p. 259.

73. Gutiérrez y Zurita, «El Trienio Constitucional..., op. cit., p. 103.

74. R. Arnabat, La revolució de $1820 \ldots$.., p. 124.

75. A. Gil Novales, Las sociedades patrióticas..., op. cit., p. 62; y Álvaro Paris Martin, «Artesanos y política en Madrid durante el resistible ascenso del liberalismo (1808-1833)», Revista THEOMA. Estudios críticos sobre Sociedad y Desarrollo, no 31, 2015, p. 43-63, especialmente p. 54-55.

76. A. Gil Novales, Las sociedades patrióticas..., op. cit., p. 90-91.

77. R. Arnabat, La revolució de 1820..., op. cit., p. 122.

78. A. Sánchez Carcelén, «La Milícia Nacional..., p. 216, y R. Vallverdú, El suport..., op. cit., p. 166.

79. A. Sánchez Carcelén, «La Milícia Nacional..., op. cit., p. 215.

80. C. Calles, La Milicia..., op. cit., p. 199 y 328.

81. J. S. Pérez Garzón, Milicia Nacional..., op. cit., p. 296-297.

82. J. S. Pérez Garzón, Milicia Nacional..., op. cit., p. 356-363.

83. R. Arnabat, La revolució de $1820 . . .$, p. 123.

84. Fermín Muñoz Echabeguren, «El Trienio Liberal (1820-1823) y la invasión francesa en San Sebastián (1823-1826)», BEHSS, nº 40, 2006, p. 347-368.

85. Carlos Rilova Jericó, «El precio de la Libertad. Apuntes para una descripción de la primera guerra civil española de la Edad Contemporánea. San Sebastián y sus liberales en 1823», BEHSS, nº 48, 2015, p. 239-354.

86. A. Gil Novales, Las sociedades patrióticas..., op. cit., p. 139.

87. Jordi Roca Vernet, La Barcelona revolucionària i Liberal: exaltats, milicians i conspiradors, Lleida, Pagès, 2011, p. 171.

88. Juan Francisco Fuentes y Pilar Garí, Amazonas de la libertad. Mujeres contra Fernando VII, Madrid, Marcial Pons Historia, 2014, p. 86.

89. Diario Constitucional, Político y Mercantil de Barcelona «Constitución o Muerte», no 177, 26 de junio de 1821. p. 3-4.

90. Diario Constitucional, Político y Mercantil de Barcelona, $\mathrm{n}^{\mathrm{o}}$ 165, 14 de junio de 1821. p. 3-4.

91. C. Calles, La Milicia..., op. cit., p. 208.

92. C. Calles, La Milicia..., op. cit., p. 186, 212 y 255.

93. Diario de Barcelona, 13 de agosto de 1823, en F. Dueñas, La Milicia Nacional..., vol. 1, p. 477.

94. Indicador Catalán, 23 de julio de 1823, en F. Dueñas, La Milicia Nacional..., vol. 1, op. cit., p. 474.

95. Diario de Barcelona, 19 de julio de 1823, en F. Dueñas, La Milicia Nacional..., vol. 1, op. cit., p. 478.

96. Actas del ayuntamiento de Barcelona, 2 de agosto de 1823, en F. Dueñas, La Milicia Nacional..., vol. 1 , op. cit., p. 478.

97. María Cruz Romeo, Entre el orden y la revolución. La formación de la burguesía liberal en la crisis de la monarquía absoluta. (1814-1833), Alicante, Instituto de Cultura, Juan Gil-Albert, Alicante, 1993.

98. Jordi Roca Vernet, «Las plazas y la representación de la nación liberal, Barcelona 1820-1857»; Pere Gabriel, Jordi Pomés y Francisco Fernández (dir.), España Res publica. Nacionalización española e identidades en conflicto (siglos XIX y XX), Granada, Editorial Comares, 2013, p. 11-23.

99. Albert García Balañá, «"El verdadero productor”: Lenguaje y experiencia en la formación de las culturas políticas obreras», Mª Cruz Romeo y Mª Sierra, (coords.), La España liberal, 1833-1874, Vol. II, en Manuel Pérez Ledesma e Ismael Saz, (dir.), Historia de las culturas políticas en España y América Latina, Madrid, Marcial Pons Historia y Prensas Universitarias de Zaragoza, 2014, pp. 217-252.

100. A. Gil Novales, Las sociedades patrióticas..., op. cit., p. 117. 
101. J. S. Pérez Garzón, Milicia Nacional..., op. cit., p. 179, y J. F. Fuentes, «Milicia Nacional»..., op. cit., p. 444.

102. Diario Constitucional, Político y Mercantil de Barcelona, $\mathrm{n}^{\circ}$ 128, 18 de julio 1820, p. 2-3.

103. Jordi Roca Vernet, «Ciutadans: industrials, menestrals i obrers. De l'Escola Pia de Sant Antoni als carrers de Barcelona», L'Escola Pia de Sant Antoni: dos-cents anys al barri i a Barcelona, Barcelona, Ajuntament de Barcelona, 2016, p. 76-110.

104. Diario Constitucional, Político y Mercantil de Barcelona, nº 22, 22 de enero de 1821, p. 4

105. Alfredo Sáenz-Rico Urbina, La educación general en Cataluña durante el trienio constitucional, (1820-1823), Barcelona, Universidad de Barcelona, 1973, p. 48.

106. Joaquín Catalá, Prólogo del método y plan de enseñanza e instrucción pública que el P. Lector en Sagrada Teología Fr... del orden de Trinitarios Calzados da á luz para sus beneméritos conciudadanos de la Academia Cívica de Barcelona, Barcelona, En la imprenta Nacional de la Viuda de D. Agustín Roca, Impresor de Cámara de S. M., 1820, p. 4.

107. A. Sáenz-Rico Urbina, La educación general..., op. cit., p. 192-195.

108. A. Sáenz-Rico Urbina, La educación general..., op. cit., p. 198-200.

109. C. Calles, La Milicia..., op. cit., p. 329.

110. Diario Constitucional, Político y Mercantil de Barcelona, $n^{\circ}$ 53, 22 de febrero de 1821, p. 1-3; y Diario Constitucional, Político y Mercantil de Barcelona «Constitución o Muerte», no 330, 27 de noviembre de 1821., p. 2-4.

111. F. Dueñas, La Milicia Nacional..., vol. 1, op. cit., p. 255.

112. J. F. Fuentes, «Milicia Nacional»..., op. cit., p. 444.

113. Diario de la ciudad de Barcelona ó sea El Eco de la Ley, no 48, 17 de junio de 1822, p. 3-4.

114. Arxiu Històric de la Ciutat de Barcelona (AHCB). Consellers 35, oficio del 19 de junio de 1822, en F. Dueñas, La Milicia Nacional..., vol. 1, p. 221.

115. M. R. Gutiérrez y R. Zurita, «El Trienio Constitucional... op. cit., p. 103.

116. M. Codesal, La ciudad de Zamora..., op. cit., p. 243.

117. M. Codesal, La ciudad de Zamora..., op. cit., p. 246.

118. J. Mª. García León, La Milicia Nacional en Cádiz..., op. cit., p. 113.

119. M. Codesal, La ciudad de Zamora..., op. cit., p. 189.

120. C. Calles, La Milicia..., op. cit., p. 54.

121. M. Codesal, La ciudad de Zamora..., op. cit., p. 253.

122. J. S. Pérez Garzón, Milicia Nacional..., op. cit., p. 241.

123. A. Guillén, Una aproximación al Trienio..., op. cit., p. 109.

124. J. S. Pérez Garzón, Milicia Nacional..., op. cit., p. 259.

125. C. Calles, La Milicia..., op. cit., p. 92.

126. C. Calles, La Milicia..., op. cit., p. 149-151 y 257.

127. L. Sorando y A. Manzano, «La Milicia Nacional..., op. cit., p. 194.

128. F. Dueñas, La Milicia Nacional..., vol. 1, op. cit., p. 442-444.

129. Diario de Barcelona, 24 de enero de 1823, en F. Dueñas, La Milicia Nacional..., vol. 1, op. cit., p. 251.

130. Plan de la Diputación Provincial de Barcelona para combatir a los insurrectos de los «facciosos», Archivo histórico de la Diputación Provincial de Barcelona, en F. Dueñas, La Milicia Nacional..., vol. 1, op. cit., p. 369-376.

131. Ramon Arnabat, Visca el Rei i la Religió. La primera guerra civil de la Catalunya Contemporània (1820-1823), Lleida, Pagès Editors, 2006, 166.

132. Diario de la ciudad de Barcelona, $\mathrm{n}^{\circ}$ 49, 18 de febrero de 1823, p. 424.

133. F. Dueñas, La Milicia Nacional..., vol. 1, op. cit., p. 424-425. 
134. Manuel Morán, «Los emigrados italianos de 1821 en la guerra de Cataluña», Italica. Cuadernos de Trabajo de la Escuela Española de Historia y Arqueología de Roma, nº 18, 1990, p. 329-363..., op. cit., pp. 358-360; y Agostino Bistarelli, Gli Esuli del Risorgimento, Il Mulino, Bologna, 2011, p. 100-101.

135. F. Dueñas, La Milicia Nacional..., vol. 2, op. cit., p. 398.

136. Juan Luis Simal, Emigrados España y el exilio internacional, 1814-1834, Madrid, CEPC, 2012, p. 156-157.

137. Laurent Nagy, «La légion libérale étrangère», Parlement(s). Revue d'histoire politique, $\mathrm{n}^{\circ}$ 22, 2013, p. 1-20; Walter Bruyère-Ostells, «Les officiers de la grande armée dans l'Espagne Libérale de 1823», Revue de l'Institut Napoléon, nº 186, 2003, pp. 55-78; y Laurent Nagy, «Un conspirateur républicain-démocrate sous la Restauration: Claude-François Cugnet de Montarlot. Origine de l'élaboration d'une culture révolutionnaire», Annales Historiques de la Révolution Française, nº 4, 2012, p. 131-156.

138. A. Mejide Pardo, «Guerra Civil de 1823..., op. cit., p. 237-252.

139. Manifiesto que los alumnos de la Universidad Mayor de Santiago ofrecen al público de las funciones que en los días 26 y 27 de abril de 1822, han celebrado en obsequio de la Bandera que fue del Batallón Literario, que en 808 se formó de la juventud de aquella escuela, y mandada entregar por el gobierno al claustro de dicha Universidad, En dicha ciudad, Imprenta de D. Juan Francisco Montero, 1822.

140. C. Calles, La Milicia..., op. cit., p. 50-51.

141. C. Calles, La Milicia..., op. cit., p. 240.

142. C. Calles, La Milicia..., op. cit., p. 116.

143. F. Dueñas, La Milicia Nacional..., vol. 1, op. cit., p. 256.

144. F. Dueñas, La Milicia Nacional..., vol. 1, op. cit., p. 260.

145. F. Llanos, El Trienio Liberal en Guipúzcoa..., op. cit., p. 441.

146. L. Sorando y A. Manzano, «La Milicia Nacional..., op. cit., p. 186.

147. A. Gil Novales, Las sociedades patrióticas..., op. cit., p. 686.

148. El Indicador Catalán, nํ2 229, 17 de agosto de 1823, p. 2; y l Indicador Catalán, no 231, 19 de agosto de 1823 , p. 4.

149. F. Dueñas, La Milicia Nacional..., vol. 1, op. cit., p. 208.

150. Diario Constitucional, Político y Mercantil de Barcelona, ํo 291, 31 de diciembre de 1820, p. 4.

151. F. Dueñas, La Milicia Nacional..., vol. 2, op. cit., p. 68, art. 19.

152. Jordi Roca Vernet, «La Revolución Liberal en España en clave trasnacional a través de la Amazona Emilia du Guermeur, viuda de la Luis Lacy», Lacy, Revista de Estudios Sanroqueños, ㄲo 5, 2017, p. 67-86.

153. Jordi Roca Vernet, «Emilia Duguermeur de Lacy, un liderazgo femenino en el liberalismo español», Irene Castells; Gloria Espigado y Mª Cruz Romeo (ed.), Las heroínas de la Guerra de la Independencia, Madrid, Cátedra, 2009, p. 367-393.

154. Indicador Catalán, 7 de setiembre de 1823, p. 3.

155. F. Dueñas, La Milicia Nacional..., vol. 1, op. cit., p. 202-203.

156. Rodrigo Moreno Gutiérrez, La Trigarancia. Fuerzas armadas en la consumación de la independencia. Nueva España, 1820-1821, México D. F., Universidad Nacional Autónoma de México, Instituto de Investigaciones Históricas, 2016, p. 91.

157. J. F. Fuentes, «Milicia Nacional»..., op. cit., p. 444.

158. Sergio Paolo Solano, «Artesanos de color y milicias en Hispanoamérica: la vida política al interior de las milicias y la aspiración a la igualdad en el tránsito entre los siglos XVIII y XIX», Conferencia leída en el Simposio Internacional. Cultura política y subalternidad en Latinoamérica, Universidad Pedagógica Tecnológica de Colombia, Tunja, 2017, p. 38-39. 


\section{RESÚMENES}

La milicia nacional fue el principal instrumento de formación política y movilización social del liberalismo. Sin embargo, paradójicamente ha recibido poca atención por parte de los historiadores. Este artículo demuestra cómo el liberalismo revolucionario pudo subsistir en las filas de la milicia durante el Trienio Liberal y en consecuencia se erigió en un contrapoder capaz de presionar y desafiar a las instituciones liberales. La movilización de la milicia se basó en un discurso político que rebasaba los límites establecidos por la interpretación moderada de la Constitución de 1812 y apelaba un proyecto político revolucionario basado en la tendencia universalista e igualitaria del liberalismo.

La milice nationale fut l'instrument principal de formation politique et de mobilisation sociale du libéralisme. Cependant, et paradoxalement, elle n'a guère suscité l'attention des historiens. Cet article montre comment le libéralisme révolutionnaire a pu persister dans les rangs de la milice pendant le Triennat Libéral et, de ce fait, s'est érigé en contrepouvoir capable de faire pression et de défier les institutions libérales. La mobilisation de la milice s'est fondée sur un discours politique qui dépassait les limites établies par l'interprétation modérée de la Constitution de 1812 et faisait appel à un projet politique révolutionnaire fondé sur la tendance universaliste et égalitaire du libéralisme.

The national militia was the main instrument of political formation and social mobilization of liberalism. However, paradoxically it has received little attention from historians. This article demonstrates how revolutionary liberalism could survive in the ranks of the militia during the Liberal Triennium and, consequently, it became a counter power capable of pressuring and challenging the liberal institutions. The mobilization of the militia was based on a political discourse that went beyond the limits established by the moderate interpretation of the Constitution of 1812 and appealed a revolutionary political project based on the universalist and egalitarian tendency of liberalism.

\section{ÍNDICE}

Keywords: National Militia, Revolutionary Liberalism, Citizenship, Popular Radicalism, Institutional Liberalism, Popular classes

Palabras claves: Milicia Nacional, Liberalismo revolucionario, Ciudadanía, Radicalismo popular, Liberalismo institucional, Clases populares

Mots-clés: Milice nationale, libéralisme révolutionnaire, citoyenneté, radicalisme populaire, libéralisme institutionnel, classes populaires

\section{AUTOR}

\section{JORDI ROCA VERNET}

Universitat de Barcelona 